\title{
Calcium from salmon and cod bone is well absorbed in young healthy men: a double- blinded randomised crossover design
}

\author{
Marian K Malde ${ }^{1 *}$, Susanne Bügel ${ }^{2}$, Mette Kristensen ${ }^{2}$, Ketil Malde ${ }^{3}$, Ingvild E Graff ${ }^{1}$, Jan I Pedersen ${ }^{4}$
}

\begin{abstract}
Background: Calcium (Ca) - fortified foods are likely to play an important role in helping the consumer achieve an adequate $\mathrm{Ca}$ intake, especially for persons with a low intake of dairy products. Fish bones have a high Ca content, and huge quantities of this raw material are available as a by-product from the fish industry. Previously, emphasis has been on producing high quality products from fish by-products by use of bacterial proteases. However, documentation of the nutritional value of the enzymatically rinsed Ca-rich bone fraction remains unexplored. The objective of the present study was to assess the bioavailability of calcium in bones of Atlantic salmon (oily fish) and Atlantic cod (lean fish) in a double-blinded randomised crossover design.

Methods: Ca absorption was measured in 10 healthy young men using ${ }^{47} \mathrm{Ca}$ whole body counting after ingestion of a test meal extrinsically labelled with the ${ }^{47} \mathrm{Ca}$ isotope. The three test meals contained $800 \mathrm{mg}$ of $\mathrm{Ca}$ from three different calcium sources: cod bones, salmon bones and control $\left(\mathrm{CaCO}_{3}\right)$.

Results: Mean Ca absorption ( \pm SEE) from the three different Ca sources were $21.9 \pm 1.7 \%, 22.5 \pm 1.7 \%$ and $27.4 \pm$ $1.8 \%$ for cod bones, salmon bones, and control $\left(\mathrm{CaCO}_{3}\right)$, respectively.

Conclusion: We conclude that bones from Atlantic salmon and Atlantic cod are suitable as natural Ca sources in e.g. functional foods or as supplements.
\end{abstract}

\section{Background}

In recent years, emphasis has been put in producing high quality nutritional products from fish by-products by use of enzymes $[1,2]$. The bone fraction, which comprises approximately $10-15 \%$ of the total body weight of fish (skin not included) is still regarded as waste. The Norwegian fisheries produce more than 600,000 tons of by-products annually [3], which is more than $20 \%$ of the gross weight of fish caught and farmed in Norway. Most of the byproducts are used as low quality raw materials for feed production, and about 180,000 tons are dumped into the sea [3]. Thus, scientific documentation of content and use of various components from marine by-products for human consumption is warranted.

Fish bone has a high calcium (Ca) content, and $\mathrm{Ca}$ and phosphorus (P) comprise about $2 \%(20 \mathrm{~g} / \mathrm{kg}$ dry

\footnotetext{
* Correspondence: mma@nifes.no
'National Institute of Nutrition and Seafood Research, PO Box 2029 Nordnes,

* Correspondence: mma@nifes.no
'National Institute of Nutrition and Seafood Research, PO Box 2029 Nordnes, N-5817 Bergen, Norway
}

(c) 2010 Malde et al; licensee BioMed Central Ltd. This is an Open Access article distributed under the terms of the Creative Commons Attribution License (http://creativecommons.org/licenses/by/2.0), which permits unrestricted use, distribution, and reproduction in any medium, provided the original work is properly cited.

weight) of the whole fish. The chemical composition of fish bones varies, and in general, oily fish (e.g. salmon) have higher lipid levels, and lower protein and ash levels compared to lean species (e.g. cod) [4]. Also the bone structure differs between species since a large number of teleosts have acellular bone (bone without enclosed osteocytes). Cellular bones are confined to only a few fish groups, e.g. Salmonidae. There is no consensus for the functional role of acellular bone, and even though a lower mineral level probably is correlated to low stiffness, although this has not been verified experimentally [5]. The crystals in acellular bone are smaller and more easily stained than in cellular bone [6]. This higher surface to volume ratio in acellular fish bone is likely to increase the $\mathrm{Ca}$ availability compared to cellular bone. In support of this, a higher Ca availability in acellular eel bone compared to the cellular rat bone was described already in 1974 by [7]. Small fresh water fish are often eaten whole, including bones. Ca from such fish has been shown to have comparable absorption to 
Ca from skimmed milk both in rats [8] and humans [9]. In another study by Jung et al. [10], Ca retention was increased and loss of bone mineral was decreased by fish bone peptide supplementation in ovariectomised rats. A recent study in growing pigs have shown that $\mathrm{Ca}$ from salmon, cod and saithe bones is absorbed as efficiently as $\mathrm{CaCO}_{3}[11]$. The study also indicated that fish species and rinsing method may be of importance both for nutritional content and absorption. Ca-fortified foods are likely to play an important role in helping consumers to meet the calcium requirements needed to reduce the risk of osteoporosis. Thus, there is a need for evaluating $\mathrm{Ca}$ absorption from different types of fish bone against other commercially available products. To the authors' knowledge, no study has compared $\mathrm{Ca}$ absorption from fish bone by-products with other $\mathrm{Ca}$ sources in humans.

The objective of the present study was to evaluate bone by-product from fish as a Ca source in humans. The nutritional composition of fish bones was compared to commercially available calcium supplements, and $\mathrm{Ca}$ absorption from enzymatically rinsed fish bones from an oily fish species with cellular bone (Atlantic salmon) and a lean fish species with acellular bone (Atlantic cod), was assessed in young men using ${ }^{47} \mathrm{Ca}$ whole body counting. $\mathrm{CaCO}_{3}$ was used as control.

\section{Subjects and Methods}

\section{Study design}

Three different test meals containing $800 \mathrm{mg}$ Ca from different sources labelled with ${ }^{47} \mathrm{Ca}$ were tested in 10 subjects using whole body counting three times during a 4-week period after the ingestion of the test meal. The three test meals were tested according to a doubleblinded randomised crossover design, where the subjects were randomly assigned to the sequence of the test meals and there was a wash out period of 7 weeks between the three test meals (Figure 1). To maintain the subjects' calcium intake constant at the time of the test meals, a standardised experimental diet was provided for two days before and three days after ingestion of the test meal corresponding to the individual subjects' habitual $\mathrm{Ca}$ intake. In the remaining time between the test meals, the subjects consumed a self-selected diet. The study was approved by the Municipal Ethical Committee of Copenhagen and Frederiksberg (KF-01270319), and the National Institute of Radiation Hygiene, Denmark.

\section{Subjects}

Eleven young healthy men (age: $26 \pm 4$ y; BMI: $24 \pm 2$ $\mathrm{kg} / \mathrm{m}^{2}$ ) were recruited for this experimental study through postings at universities in the Copenhagen area (Table 1). The number of subjects was chosen based on experience from previous studies $[12,13]$. The subjects

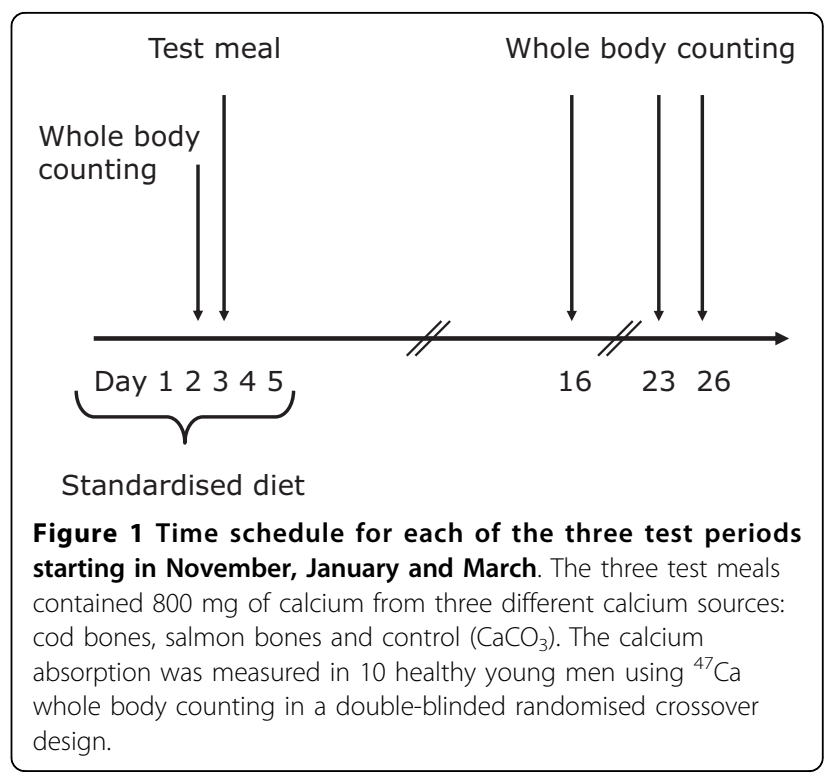

were all non-smokers, none of the subjects exercised $>10 \mathrm{~h} /$ week, took dietary supplements two months prior to start of the study and during the study, were lactose intolerant, had previously participated in studies using radioisotopes, or suffered from any chronic illnesses of relevance to the study. One subject dropped out during the first experimental period for reasons not related to the study. The subjects were given oral and written information about the study, and written consent was obtained from all subjects. After completion of the three meal tests, the subjects received 3000 DKK (US\$ 500).

\section{The standardised experimental diet}

To keep the subjects' Ca intake constant, a standardised experimental diet was provided two days before the test meal and three days after. The diet was designed to match the subjects' individual habitual calcium intake, which was assessed using a food frequency questionnaire aimed at calcium intake [14] and had an energy distribution corresponding to the habitual Danish diet (15 E\% from protein, $35 \mathrm{E} \%$ from fat and $50 \mathrm{E} \%$ from carbohydrates). The subjects had the same food items for lunch, dinner and snack meal whereas their breakfasts differed due to the different Ca intakes. The diet consisted of common Danish food items such as rye bread, pasta and rice dishes, fruits, juice and candy. Breakfast meals differed and consisted of breakfast cereals, milk, juice, fruit, breads, cheese and jam. The energy intake was estimated by calculation of the subjects basal metabolic rate $(\mathrm{BMR}=$ $0.064 * \mathrm{~W}+2.84)[15]$ multiplied by a physical activity level (PAL) factor assessed individually based on a questionnaire on physical activity. All meals were prepared in advance in an experimental kitchen unit 
Table 1 Age, body mass index, estimated energy intake, estimated calcium intake (food frequency questionnaire) and chemical analysed calcium content of breakfast given in the experimental period (two days before and two days after ingestion of the test meal), a separate breakfast was provided the test day, containing 800 mg calcium for all subjects

\begin{tabular}{|c|c|c|c|c|c|c|}
\hline Subject & Age & $\begin{array}{l}\text { Body mass } \\
\text { index }\left(\mathrm{kg} / \mathrm{m}^{2}\right)\end{array}$ & $\begin{array}{l}\text { Energy } \\
\text { intake (MJ) }\end{array}$ & $\begin{array}{l}\text { Total Ca intake } \\
(\mathrm{mg} / \mathrm{d})\end{array}$ & $\begin{array}{l}\text { Ca content, breakfast } \\
\text { (mg/d) }\end{array}$ & $\begin{array}{l}\text { Ca intake, beverages } \\
\text { (mg/d) }\end{array}$ \\
\hline 1 & 24 & 20.9 & 14 & 1644 & 1172 & 22.8 \\
\hline 2 & 22 & 22.7 & 14 & 817 & 343 & 24.8 \\
\hline 3 & 22 & 24.9 & 15 & 679 & 153 & 44.0 \\
\hline 4 & 27 & 25.6 & 18 & 1512 & 896 & 37.0 \\
\hline 5 & 27 & 28.1 & 16 & 1096 & 582 & Not reported \\
\hline 6 & 34 & 24.7 & 16 & 1909 & 1362 & 32.9 \\
\hline 7 & 26 & 21.6 & 14 & 1215 & 736 & 29.1 \\
\hline 8 & 26 & 23.7 & 12 & 456 & 71 & Not reported \\
\hline 9 & 27 & 24.7 & 18 & 1675 & 1053 & 43.5 \\
\hline 10 & 22 & 23.2 & 12 & 1456 & 1038 & 31.8 \\
\hline
\end{tabular}

especially equipped to avoid trace mineral contamination. One meal was daily served at the department and the remaining foods were provided for home consumption where the hot meal could be microwave heated. The subjects were provided with mineral water $(14.2 \mathrm{mg} \mathrm{Ca} / \mathrm{l}$, Aqua D'or, Brande, Denmark) ad libitum which they also were allowed to use for making coffee and tea. The subjects were instructed to register the amount of water consumed daily and were not allowed to drink or eat anything which was not provided for them from the department.

In addition to the standardised experimental diet, the subjects were instructed to take a daily vitamin $\mathrm{D}_{3}$ supplement of $10 \mu \mathrm{g}$ (Naturdrogeriet, Herning, Denmark) for one month before the first test meal and throughout the study period to ensure an adequate vitamin D status. This was necessary as the study ran from October through March were the sun exposure in Denmark is not sufficient to maintain adequate vitamin $\mathrm{D}$ production in the skin.

\section{The test meals, isotopes and labelling procedure}

The three test meals contained $800 \mathrm{mg}$ of $\mathrm{Ca}$ from three different sources: enzymatically treated cod bones; enzymatically treated salmon bones, and control $\left(\mathrm{CaCO}_{3}\right)$, which were baked into bread rolls. The $\mathrm{Ca}$ dose was chosen to reflect a daily dose of a Ca supplement. In addition to the $\mathrm{Ca}$ containing bread roll, the test meals consisted of butter and raspberry jam (to camouflage the crunchy fish bones) and was served with $400 \mathrm{ml}$ of ultra pure water. The test persons were monitored during the meal and were given 10-15 minutes to eat. They were instructed to alternate between eating and drinking and to finish their plate. The meal was served at the Department of Human Nutrition, University of Copenhagen on the morning of the test day after a 12 hour fast and the subjects were instructed not to eat or drink for four hours after intake of the test meal.

The isotopes $\left({ }^{47} \mathrm{Ca}\right)$ were provided by Risø National Laboratory, Radiation Research Department (Roskilde, Denmark) through the Copenhagen University Hospital. The Copenhagen University Hospital received the isotopes the day before dosage of the test meals, prepared doses of $0.2 \mathrm{MBq} / \mathrm{ml}$ and transported these to Department of Human Nutrition, University of Copenhagen. Due to problems with the reactor where the isotope was produced, a lower dose was provided in the last period $\left(0.108 \mathrm{MBq}{ }^{47} \mathrm{Ca} / \mathrm{ml}\right)$, but this was corrected for in the calculation of calcium absorption. The doses were used to extrinsically label the test meals by drop-wise adding $1 \mathrm{ml}$ of isotope solution $\left(0.2 \mathrm{MBq}{ }^{47} \mathrm{Ca}\right)$ onto the cut surfaces of the rolls. The bread rolls were labelled in the afternoon on the day before intake of the test meal and stored at $5^{\circ} \mathrm{C}$ until consumption. The external tag method has previously been evaluated [9].

Since each subject received three labelled meals, a maximum dose of $0.6 \mathrm{MBq}$ was received during the study period, which resulted in an estimated maximal radiation dose of $1.5 \mathrm{mSV}$.

\section{Whole body counting}

The whole-body counter, located at the National University Hospital in Copenhagen, consists of a lead-lined steel chamber with four plastic scintillator blocks (NE110, Nuclear Enterprises Limited, Edinburgh) connected to conventional nuclear electronic modules and a multichannel analyzer system. The counting efficiency and the settings of the energy window were established though measurements of three water-filled phantoms each containing ${ }^{47} \mathrm{Ca}$ activity corresponding to a meal and with weights 55,66 , and $77 \mathrm{~kg}$. The individual measurements lasted for $10 \mathrm{~min}$. To minimize contamination by 
atmospheric background activity, the subjects had a shower and hair wash and were dressed in hospital clothing before each measurement.

\section{Calcium sources tested}

Four different $\mathrm{Ca}$ supplements were obtained from a local pharmacy and health store, analysed and evaluated as source for $\mathrm{Ca}$ control. The source of $\mathrm{Ca}$ in the products differed; being apatite, oyster shell, algae (Lithothamnion calcareum), and $\mathrm{CaCO}_{3}$. We decided on using $\mathrm{CaCO}_{3}$ as control in the present study.

Four different fish bone sources were analysed and evaluated as $\mathrm{Ca}$ source for the experimental diets. The sources were salmon and cod bones where soft tissue was removed by use of two different methods, boiling or by use of industrialised produced enzymes. The fish bones rinsed by use of enzymes were chosen as $\mathrm{Ca}$ source in the present study. The cod bone was provided by Maritex (Sortland, Norway), and the bones had been rinsed enzymatically by use of Papain $(6000 \mathrm{NFPU} / \mathrm{mg}$, Biochem Europe, Mons, Belgium). Bones from fresh salmon (Salmo salar) were provided by BioMega A/S, Sotra, Norway. The frames were treated at BioMega A/S with industrially produced enzymes (proteases) [2], similar to protamex (Novozymes A/S, Bagsværd, Denmark). The salmon bones were then rinsed for soft tissue in running cold water using forceps. The cleaned bone samples were freeze dried (Hetosicc, Heto, Denmark) for 74 hours and thereafter ground (Knifetec mill, Foss Tecator). A detailed example of the enzymatic process is described elsewhere [1]. $\mathrm{CaCO}_{3}$ produced for human consumption (Merck KGaA, Darmstadt, Germany) served as a control source of $\mathrm{Ca}$.

\section{Chemical analyses}

Representative samples of the Ca supplements and fish bone were analysed in duplicate. The total fat content of the samples was determined gravimetrically after extraction with ethyl acetate [16]. The ash concentration was likewise determined gravimetrically by burning all organic substances in a programmable furnace where the temperature was gradually increased from ambient to $550^{\circ} \mathrm{C}$ and held at this temperature for 20 hours until constant weight. Total nitrogen was determined using a nitrogen element analyser (LECO, FP-528 N-analyser, Leco Corporation Svenska AB, Sweden). Protein was calculated as $\mathrm{N} \times 6.25$.

Prior to the determination of the elements, subsamples were submitted to microwave-assisted wet digestion using $2.0 \mathrm{~mL} \mathrm{HNO}_{3}$ (ultra pure quality) and $0.5 \mathrm{~mL}$ $\mathrm{H}_{2} \mathrm{O}_{2}$, in an Ethos Pro microwave system (Milestone, Holger Teknologi, Oslo, Norway). Flame Atomic Absorption Spectrometry (Perkin-Elmer 3300 AAS, Norwalk, CT) was used for the determination of the elements $\mathrm{Na}, \mathrm{K}, \mathrm{Mg}, \mathrm{Ca}$ and $\mathrm{Fe}([17,18])$. Quantification was made by means of external calibration. Hallow cathode lamps (HCL) were used for magnesium, calcium and iron, whereas sodium and potassium were run in emission mode. The effect of the nitrate concentration present in the sample solutions on the $\mathrm{Ca}$ signal were tested [17] and no suppression effect was found. The concentration of $\mathrm{P}$ was determined by electrothermal atomic absorption spectrometry on a Zeeman Atomic Absorption Spectrometer (Perkin Elmer 4110 ZL, Norwalk, CT) equipped with na THGA graphite furnace and an AS 72 autosampler. Palladium and magnesium were used as matrix modifier. An Agilent Quadrupole ICP-MS 7500c instrument (Yokogawa Analytical Systems, Inc., Tokyo, Japan) was used as a specific detector for the essential elements: $\mathrm{Cu}, \mathrm{I}, \mathrm{Mn}, \mathrm{Se}$ and $\mathrm{Zn}$ and the non-essential elements $\mathrm{As}, \mathrm{Cd}, \mathrm{Hg}$ and $\mathrm{Pb}$ Six points calibration solutions $(5-100 \mu \mathrm{l} / \mathrm{L})$ were prepared daily by appropriate dilution of $1000 \mathrm{mg} / \mathrm{L}$ stock solution of the elements in question (Spectrascan, Teknolab AS, Drøbak, Norway). A diluted solution of a $1000 \mathrm{mg} / \mathrm{L}$ (in $10 \% \mathrm{HCl}$ ) certified rhodium stock solution (Spectroscan) was added online and served as an internal standard. Iodine was determined by ICP-MS after the samples were extracted in tetramethylammonium hydroxide (TMAH) for $3 \mathrm{~h}$ at $90{ }^{\circ} \mathrm{C}([19,20])$. The elemental analyses are all accredited by the Norwegian Metrology and Accreditation Service. The certified reference materials TORT-2, Lobster hepatopancreas (National Research council of Canada) and NIST Oyster Tissue (National Institute for Standards and Technology, Gaithersburg, MD, USA) were used for quality assurance of the determination of all elements analysed.

Total Ca content of duplicate portions of the experimental diets and test meals was analysed after homogenisation and microwave digestion (MES-1000, CEM Corporation, Matthews, North Carolina, USA) with HNO3 65\%, suprapur (Merck, Darmstadt, Germany) and $\mathrm{H} 2 \mathrm{O} 230 \%$, suprapur (Merck, Darmstadt, Germany) by atomic absorption spectroscopy SpectraAA-200 VARIAN (Varian Techtron Pty. Limited, Victoria, Australia) after dilution with lanthaniumoxide solution (Merck, Darmstadt, Germany) (lanthaniumoxide solution: $0.5 \%$ lanthaniumoxide, $1 \% \mathrm{HNO} 3$ and $\mathrm{H} 2 \mathrm{O}$ ). Standards were prepared from a $1000 \mathrm{mg} / \mathrm{L}$ Ca standard (Tritisol ${ }^{\circ}$, Merck, Darmstadt, Germany) by dilution with lanthaniumoxid solution. A reference diet (Standard Reference Material 1548a, Typical Diet, National Institute of Standards and Technology, Gaithersburg, MD, USA) was analysed in the same run. Analysed Ca content $1.943 \pm 0.038 \mathrm{mg} / \mathrm{g}$; certified value: $1.967 \pm 0.113$ $\mathrm{mg} / \mathrm{g}$. The coefficient of variation was $2.0 \%(\mathrm{n}=4)$.

Concentration of $25(\mathrm{OH}) \mathrm{D}$ was quantified using ${ }^{125} \mathrm{I}$ RIA kit (DiaSorin, Stillwater, USA) with an intra-assay 
of $10 \%$ and both cholecalciferol and ergocalciferol metabolites were measured. Intact PTH was quantified with an Immulite intact PTH immunoassay kit (Diagnostic Products Corporation, Los Angeles, Calif.) with an intra-assay precision of $5.8 \%$.

\section{Calculations and statistics}

It has long been known that retention of many boneseeking elements is inadequately described by a single exponential function, and that a sum of multiple exponentials presents a more accurate picture [21]. Retention $(\mathrm{R})$ after time $(\mathrm{t})$ can then be described by (1):

$$
\mathrm{R}(\mathrm{t})=\sum \alpha_{\mathrm{i}} \mathrm{e}^{-\beta_{\mathrm{i}} \mathrm{t}}
$$

For large values of $t$, this function can be accurately approximated by a power function,

$$
\mathrm{R}(\mathrm{t})=\mathrm{At}^{\mathrm{b}},-1<\mathrm{b}<0,0<=\mathrm{A}<=1
$$

where $\mathrm{A}$ is the absorption, and $\mathrm{b}$ is the rate of excretion.

This approximation reduces the number of parameters that need to be estimated to A and b, and moreover, since the power function is linear in a log-log plot, these parameters can be estimated from empirical data using linear regression on log-transformed values [21,22].

For small values of $t$, the approximation in (2) is less accurate. It is easy to see that as the exponent $b$ is negative, the retention becomes arbitrarily large as $t$ approaches zero. A more accurate function for small $t$ is also given by Norris et al. [21] as

$$
\mathrm{R}(\mathrm{t})=\mathrm{A}((\mathrm{t}+\mathrm{y}) / \mathrm{y})^{\mathrm{b}}
$$

The parameter y can be estimated empirically; the ICRP's estimate of 0.76 days for Ca (ICRP 1972), is reported to fit well with observed data [23]. However, for estimation it is simpler and more accurate to use the linear approximation (2) and samples taken sufficiently long after ingestion. Beck et al. [22] suggest sampling after day 9. In this study, measurements were taken on day 16, 23 and 26.

Whole body retention of ${ }^{47} \mathrm{Ca}$ was measured with a whole-body counter at the Copenhagen University Hospital (Rigshospitalet, Copenhagen). The individual initial radionuclide burden of the subjects was measured before the ingestion of the test meal. Thus, each test person was measured 12 times. All measurements of ${ }^{47} \mathrm{Ca}$ were corrected for background radiation and radioactive decay back to the time of administration.

All statistical analyses were performed using the Statistical Analysis System software package, version 9.1 (SAS Institute inc., Cary, N.C.). Dependent variables (absorption \% and vit D concentration) were controlled for homogeneity of variance investigation and normal distribution by investigation of residual plots, normal probability plots and histograms. None of the variables required transformation prior to analyses. An ANCOVA was used to examine the effect of treatment on absorption \%. This was performed in PROC MIXED, where subject was modeled as a random variable and vitamin D concentration at baseline of each period as covariates. Period and treatment $x$ period interaction was included as fixed variables. The effect of period on vitamin $D$ concentration was evaluated by ANCOVA, where subject was modeled as a random variable and period as a fixed variable. Posthoc pairwise comparisons were made using Tukey-Kramers adjustment. All data are presented as LS means \pm SEE unless otherwise stated and the statistical significance level is defined as $\mathrm{p}<0.05$.

\section{Results}

\section{Calcium supplements and fish bone meals}

The Ca content of the four supplements varied (Table 2). The two products containing apatite and oyster shell were low in $\mathrm{Ca}$, containing 0.04 and $24 \mathrm{~g}$ $\mathrm{Ca} / \mathrm{kg}$, respectively. The supplements containing algae $(336 \mathrm{~g} \mathrm{Ca} / \mathrm{kg}$ ) and calcium carbonate $(324 \mathrm{~g} \mathrm{Ca} / \mathrm{kg}) \mathrm{had}$ a higher $\mathrm{Ca}$ concentration. Contrary to the calcium supplements, the fish samples also contained fat and proteins. It should be recorded that the salmon and cod frames treated with enzymes had a higher Ca content and a lower fat content compared to the salmon and cod frames rinsed by boiling. Also, some differences in the concentration of various trace elements between the two differently rinsed bones were found (Table 2). The concentration of the non-essential elements in the salmon and cod frames was low. For the present trial, $\mathrm{CaCO}_{3}$ was chosen as control, while cod and salmon bones rinsed by use of enzymes were used as Ca source in the experimental groups.

\section{Calcium absorption using fish bone powders as calcium source}

Mean Ca absorption from the three different sources were $21.9 \pm 1.7 \%, 22.5 \pm 1.7 \%$ and $27.4 \pm 1.8 \%$ for cod bones, salmon bones, and control $\left(\mathrm{CaCO}_{3}\right)$, respectively (Figure 2A). The individual data is given in Table 3. There was a tendency towards an effect of treatment on $\mathrm{Ca}$ absorption after adjusting for vitamin $\mathrm{D}$ status and period $(\mathrm{p}=0.072)$ as the difference in Ca absorption from control and cod bones was close to significant $(\mathrm{p}=0.089)$. No effect of period was seen on mean Ca absorption after adjusting for treatment and vitamin D status $(\mathrm{p}=0.33)$, although it increased from period I through III (Figure 2B). Mean absorption was $22.2 \pm 1.7 \%$ in November, 23.4 $\pm 1.8 \%$ in January and $26.1 \pm 1.8 \%$ in March. 
Table 2 Proximal, mineral and elemental composition of different Ca sources

\begin{tabular}{|c|c|c|c|c|c|c|c|c|}
\hline \multirow[t]{2}{*}{ Component } & \multirow{2}{*}{$\begin{array}{l}\text { Salmon bone } \\
\text { (protease) }^{1}\end{array}$} & \multirow{2}{*}{$\begin{array}{l}\text { Salmon bone } \\
\text { (boiling) }^{1}\end{array}$} & \multirow{2}{*}{$\begin{array}{l}\text { Salmon bone } \\
\text { (protease) }\end{array}$} & \multirow{2}{*}{$\begin{array}{l}\text { Cod bone } \\
\text { (boiling) }\end{array}$} & \multicolumn{4}{|c|}{ Calcium supplement from Pharmacy or health store } \\
\hline & & & & & A & B & $\mathrm{C}$ & $D^{1}$ \\
\hline Ash $(\mathrm{g} / 100 \mathrm{~g})$ & 55.5 & 43 & 67.8 & 65.7 & 0 & 2.8 & 90.9 & 78.9 \\
\hline Protein $(\mathrm{g} / 100 \mathrm{~g})$ & 36 & 35.7 & 26.6 & 32.4 & 0.46 & 0.50 & 0.74 & 0.56 \\
\hline Fat $(\mathrm{g} / 100 \mathrm{~g})$ & 3.0 & 17.8 & $<0.2$ & 7.9 & 0 & 0 & 0 & 0 \\
\hline \multicolumn{9}{|c|}{ Minerals (g/kg dry weight) } \\
\hline $\mathrm{Ca}$ & 208 & 157 & 261 & 248 & 0.04 & 24 & 336 & 324 \\
\hline K & 1.3 & 3.2 & 0.03 & 2.3 & 0.069 & 0.083 & 1.3 & 0.095 \\
\hline $\mathrm{Mg}$ & 4.1 & 2.6 & 3.2 & 3.5 & 0.004 & 0.085 & 29 & 1.8 \\
\hline $\mathrm{Na}$ & 1.9 & 3.1 & 2.1 & 6.0 & 0.024 & 0.28 & 5.9 & 0.27 \\
\hline P & 156 & 89 & 151 & 180 & $<0.04$ & $<0.04$ & 0.95 & 0.77 \\
\hline \multicolumn{9}{|c|}{ Essential trace elements (mg/kg dry weight) } \\
\hline $\mathrm{Cu}$ & 17.1 & 4.5 & 0.5 & 3.9 & $<0.3$ & $<0.3$ & 1.0 & 0.6 \\
\hline $\mathrm{Fe}$ & 24 & 20 & 69 & 19 & $<0.5$ & 7.0 & 3500 & 150 \\
\hline । & 0.28 & $<0.02$ & 0.14 & 3.7 & n.d. & 0.11 & 16.2 & 0.06 \\
\hline $\mathrm{Mn}$ & 66 & 36 & 3.2 & 28 & $<0.02$ & 4.2 & 141.8 & 15.5 \\
\hline $\mathrm{Se}$ & 0.3 & 0.4 & 0.5 & 0.4 & $<0.1$ & $<0.1$ & 0.2 & $<0.1$ \\
\hline $\mathrm{Zn}$ & 174 & 106 & 57 & 58 & $<0.1$ & 0.5 & 8.4 & 1.9 \\
\hline \multicolumn{9}{|c|}{ Non-essential elements (mg/kg dry weight) } \\
\hline As & 0.34 & 1.5 & 0.11 & 0.61 & $<0.01$ & 0.01 & 2.53 & 1.07 \\
\hline $\mathrm{Cd}$ & $<0.01$ & $<0.01$ & $<0.01$ & $<0.01$ & $<0.01$ & $<0.01$ & 0.12 & 0.08 \\
\hline $\mathrm{Hg}$ & 0.01 & 0.02 & $<0.03$ & $<0.01$ & $<0.01$ & $<0.01$ & $<0.01$ & $<0.01$ \\
\hline $\mathrm{Pb}$ & 0.11 & 0.05 & $<0.04$ & 0.06 & $<0.02$ & 0.03 & 3.03 & 0.09 \\
\hline
\end{tabular}

Fish bones were rinsed for soft tissue by boiling or use of industrialised produced enzymes (proteases).

${ }^{1}$ Malde et al. [11].

The vitamin D status (25(OH)-D) of the subjects decreased significantly during the study period $(\mathrm{P}<$ $0.01)$ despite a daily supplementation for which reason it is included in the statistical analyses as a covariate. Vitamin D concentrations were $56.3 \pm 4.2 \mathrm{nmol} / \mathrm{l}$ (November), $47.7 \pm 4.3 \mathrm{nmol} / \mathrm{l}$ (January) and $42.5 \pm 4.2$ nmol/l (March), and posthoc analyses showed that vitamin $\mathrm{D}$ concentration in November was significantly higher compared to both January $(p=0.025)$ and March $(\mathrm{p}<0.01)$, whereas the vitamin D status in January and March did not differ $(\mathrm{p}=0.20)$ (Figure 2C).

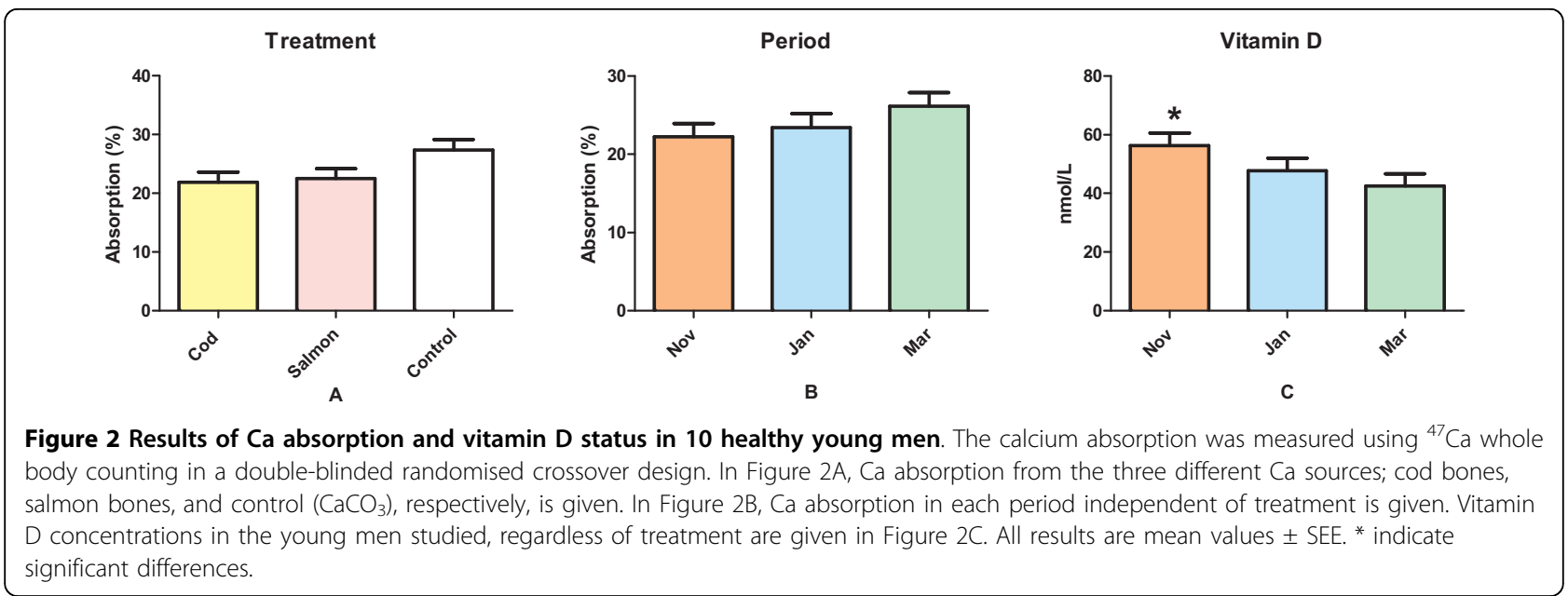


Table 3 Individual data of $\mathrm{Ca}$ absorption (\%) of ten men given enzymatically rinsed salmon (B) or cod bones (C) in a test meal

\begin{tabular}{lllll}
\hline $\begin{array}{l}\text { Subject } \\
(\mathbf{N}=\mathbf{1 0})\end{array}$ & $\begin{array}{l}\text { Order } \\
\text { of test meal } \\
\text { administration }\end{array}$ & Control (A) & Salmon (B) & Cod (C) \\
\hline 1 & CAB & 26 & 20 & 15 \\
2 & $\mathrm{BCA}$ & 27 & 24 & 20 \\
3 & $\mathrm{CAB}$ & 28 & 24 & 18 \\
4 & $\mathrm{BCA}$ & 25 & 15 & 23 \\
5 & $\mathrm{BCA}$ & 30 & 19 & 21 \\
6 & $\mathrm{ABC}$ & 23 & 23 & 30 \\
7 & $\mathrm{CAB}$ & 22 & 32 & 26 \\
8 & $\mathrm{ABC}$ & 21 & 24 & 23 \\
9 & $\mathrm{CAB}$ & 30 & 25 & 22 \\
10 & $\mathrm{ABC}$ & - & 20 & 18 \\
\hline
\end{tabular}

$\mathrm{CaCO}_{3}(\mathrm{~A})$ was given as control.

The levels of parathyroid hormone (PTH) was analysed in the start of the study. The results were within normal range (data not shown).

The average daily energy intake was $14.9 \pm 2.1 \mathrm{MJ}$. The age, body mass index, estimated energy intake, estimated calcium intake and chemical analyses of calcium content of breakfast are given in Table 1.

\section{Discussion}

Ca from the two types of fish bone was absorbed equally well, and the absorption was not significantly different from the control (Figure 2A). The present findings are in accordance with the study by Hansen et al. [9] where $\mathrm{Ca}$ absorption from small fresh-water fish was studied. A Ca absorption between 23 and $27 \%$ is considered to be within the normal range for calcium salts [24], although several studies also report higher absorption rates [22,23,25]. A meta-analysis of 15 studies (184 healthy subjects) indicated that $\mathrm{Ca}$ absorption is highest when $\mathrm{Ca}$ source is taken as part of or together with a meal [26]. In the present study, Ca absorption ranged from 15 to $32 \%$ (Table 3), with mean values of 21.9 and $22.5 \%$ for cod and salmon bones, respectively, and $27.4 \%$ for the control $\left(\mathrm{Ca} \mathrm{CO}_{3}\right)$.

An interesting observation in the present study is the effect of period on $\mathrm{Ca}$ absorption (Figure 2B). This increase cannot be due to carry-over effect of ${ }^{47} \mathrm{Ca}$, as the calculations of absorption compensate for radiation by including a whole body measurement the day before the subjects receive the test meal. Also, background radiation is accounted for in the mathematical model for calculation of absorption. The periodic increase in $\mathrm{Ca}$ absorption is also in contrast to a periodic reduction in vitamin D status (Figure 2C) during the study period despite vitamin $\mathrm{D}$ supplementation. The subjects were given $10 \mu \mathrm{g}$ of vitamin $\mathrm{D}$ daily from 4 weeks prior to the first test meal and throughout the study period to maintain a serum level of $25 \mathrm{OH}$-vitamin D of $50 \mathrm{nmol} / \mathrm{L}$. The subjects were closely followed by the staff, and all subjects claimed to have taken their daily supplement. A sample of the supplement given was analysed 25 months after study termination to test the vitamin D concentration. The analyses showed that the tablets on average contained $9.1 \mu \mathrm{g}$ vitamin D. Thus, the observed decreases in vitamin D status was unexpected since supplementation during winter has been associated with increase in serum concentration [27], also for younger men [28]. Our findings are however in line with recent evidence suggesting that the daily vitamin $\mathrm{D}$ requirement for maintenance of a $25 \mathrm{OH}$-vitamin D level $\geq 50 \mathrm{nmol} / 1$ might be as high as $\sim 30 \mu \mathrm{g} /$ day [29]. As the three different treatments were given in random order to the subjects, the observed decrease in vitamin $\mathrm{D}$ status and the periodic increase in the $\mathrm{Ca}$ absorption are not believed to have influenced the absorption differences observed between the different treatments.

The external tag method was not verified in the present study, but we assume that the added ${ }^{47} \mathrm{Ca}$ equilibrated with the $\mathrm{Ca}$, naturally occurring in fish bones. In Hansen et al. [9], the external labelling method of small soft-boned fish was evaluated by an in vitro method and compared to skimmed milk. It was concluded that the extrinsic tag method was valid for small fish containing bone, although the test also indicated that some of the native $\mathrm{Ca}$ did not equilibrate completely with the external ${ }^{47} \mathrm{Ca}$ either in the milk or the fish.

Several studies have compared different sources of $\mathrm{Ca}$, and there is no single compound pointed out as a better source than others. However, phosphate containing $\mathrm{Ca}$ supplements have been suggested as preferable to carbonate or citrate salt [30] in the treatment of osteoporosis. Fish bones have a naturally high content of both $\mathrm{Ca}$ and $\mathrm{P}$, although content varies with species, bone type (acellular vs cellular) and rinsing method. The ash content is highest in lean fish species with acellular bones, e.g. cod and saithe, compared to salmon bones. The protein content is quite similar, while salmon bones contain more fat than cod and saithe bones (Table 2). In the present study, the difference in nutritional composition did not appear to affect on the absorption.

$\mathrm{Ca}$ content is an important factor when considering how well a raw material is suitable as food supplements. If the Ca content is too low, a tablet becomes too large to be swallowed, or the number of pills in order to obtain an adequate intake of $\mathrm{Ca}$ will be too high. $\mathrm{CaCO}_{3}$ is the Ca salt most widely used as a nutritional supplement because of its high elemental calcium content (approximately 40\%). In this study we also wanted to compare fish bones with commercially available calcium supplement. Four different $\mathrm{Ca}$ supplements were 
therefore bought in a local health store and pharmacy, and the content of different components were analysed chemically. Two of the Ca supplements contained only traces or small amounts of calcium (Table 2). This was surprising since the supplements were supposed to contain apatite and oyster shell. Most likely these supplements are meant to enhance calcium absorption rather than providing $\mathrm{Ca}$. The two supplements containing either algae (Lithothamnion calcareum) or $\mathrm{CaCO}_{3}$ had high calcium content, and the algae product had in fact higher Ca concentration than declared (34\% Ca compared to $28 \% \mathrm{Ca}$ ). The calcium content of the fish bone samples tested varied from 16 and $26 \%$ and was highest in the lean fish species with acellular bone structure rinsed by use of industrialised produced enzymes (Table 2). Thus, fish bones have a slightly lower $\mathrm{Ca}$ content than, $\mathrm{CaCO}_{3}$ but comparable with other $\mathrm{Ca}$ salts like Ca-citrate $\left(\mathrm{Ca}_{3}\left(\mathrm{C}_{6} \mathrm{H}_{5} \mathrm{O}_{7}\right)_{2}\right)$, Ca-gluconat $\left(\mathrm{C}_{6} \mathrm{H}_{11} \mathrm{O}_{7} \times 1 / 2\right.$ $\mathrm{Ca})$, Ca-lactate $\left(\mathrm{Ca}\left(\mathrm{C}_{3} \mathrm{H}_{5} \mathrm{O}_{3}\right)_{2}\right)$ and $\mathrm{Ca}$-acetate $(\mathrm{Ca}$ $\left.\left(\mathrm{C}_{2} \mathrm{H}_{3} \mathrm{O}_{2}\right)_{2}\right)$ ranging from 9 to $25 \%$ [31], and higher than two of the commercially available Ca supplements analysed in the present study.

$\mathrm{CaCO}_{3}$ supplement was chosen as control in the present study since it is considered a generally accepted reference calcium source in digestibility studies [32]. The fish bones rinsed by use of industrialised produced enzymes were chosen as calcium source in the experimental groups because they had a higher calcium content than bones rinsed by boiling and because previous studies showed a tendency of better absorption [11].

For an efficient utilisation, fish bones need to be softened. Bones may be softened by heating or treatment with acid [33-35] and the softening increases with cooking time [36]. The softening of fish bone cooked in water can be explained by the elution of a small quantity of the bone proteins into the water, resulting in a change in the bone texture [36]. Softening by cooking to facilitate mastication may contribute to an increased dietary Ca uptake. The fish bones used in the present study were heated during the enzymatic treatment, but not to boiling temperature. In a previous study on pigs [11], enzymatically treated salmon bones resulted in higher $\mathrm{Ca}$ absorption than salmon bones boiled for 15 minutes. However, it is possible that even enzymatically treated fish bones may be further softened by heat treatment. Measurement of inorganic components of fish bone after heating revealed that minerals such as $\mathrm{Ca}, \mathrm{P}$ and $\mathrm{Mg}$ were mostly retained in the bone [37]. Thus, heating the bone samples for a longer period may enhance availability of $\mathrm{Ca}$ further.

\section{Conclusion}

In conclusion, fish bones are a high value by-product from the fish farm industry and due to the high calcium content this resource can conveniently be utilised as a high quality food ingredient or supplement. In the present work, the calcium in enzymatically rinsed bones from Atlantic salmon and Atlantic cod was demonstrated to be a well absorbed source of $\mathrm{Ca}$ in young, healthy men.

\section{Acknowledgements}

The project was in part supported by grant from NIFES http://www.nifes.no, RUBIN http://www.rubin.no, Innovation Norway http://www.invanor.no and the European Community -Access to Research Infrastructure Action of the Improving Human Potential Program. The authors thank Livar Frøyland for obtaining funding for the trial. The technical assistance of Berit Hoielt and Hanne Lysdal Petersen is gratefully acknowledged, and we thank the test subjects for their participation in the study.

\section{Author details}

'National Institute of Nutrition and Seafood Research, PO Box 2029 Nordnes, N-5817 Bergen, Norway. ${ }^{2}$ Department of Human Nutrition, Faculty of Life Sciences, University of Copenhagen, Rolighedsvej 30, DK-1958 Frederiksberg C. Denmark. ${ }^{3}$ Institute of Marine Research, PO Box 1870 Nordnes, N-5817 Bergen, Norway. ${ }^{4}$ Department of Nutrition, Institute of Basic Medical Sciences, University of Oslo, PO Box 1046 Blindern, N-0316 Oslo, Norway.

\section{Authors' contributions}

MKM and JIP initiated the study and together with SB and IEG were responsible for the detailed planning of the study. MK and SB were responsible for conducting the trial, and MK also performed the statistical analyses. KM was responsible for applying the Ca retention model. MKM drafted the manuscript, and all authors contributed to the interpretation of the results and final writing and approval of the manuscript.

\section{Competing interests}

The authors declare that they have no competing interests.

Received: 28 April 2010 Accepted: 20 July 2010 Published: 20 July 2010

\section{References}

1. Liaset B, Julshamn K, Espe M: Chemical composition and theoretical nutritional evaluation of the produced fraction from enzymic hydrolysis of salmon frames with Protamex TM. Process Biochem 2003, 38:1747-1759.

2. Sandnes K, Pedersen K, Hagen H: Kontinuerlig enzymprosessering av ferske marine biprodukter Trondheim, Norway, Stiftelsen RUBIN 2003, 28.

3. RUBIN: Varestømsanalyse for 2005. Stiftelsen RUBIN 2006.

4. Toppe J, Albrektsen S, Hope B, Aksnes A: Chemical composition, mineral content and amino acid and lipid profiles in bones from various fish species. Comp Biochem Physiol B Biochem Mol Biol 2007, 146:395-401.

5. Horton JM, Summers AP: The material properties of acellular bone in a teleost fish. J Exp Biol 2009, 212:1413-1420.

6. Moss ML: Osteogenesis of Acellular Teleost Fish Bone. Am J Anat 1961, 108:99-109.

7. Fenwick JC: Comparative Invitro Release of Calcium from Dried and Defatted Eel and Rat Bone Fragments, and Its Possible Significance to Calcium Homeostasis in Teleosts. Can J Zool 1974, 52:755-764.

8. Larsen T, Thilsted SH, Kongsbak K, Hansen M: Whole small fish as a rich calcium source. Br J Nutr 2000, 83:191-196.

9. Hansen M, Thilsted SH, Sandström B, Kongsbak K, T L, Jensen M, Sørensen SS: Calcium absorption from small soft-boned fish. J Trace Elem Med Biol 1998, 12:148-154.

10. Jung W-K, Lee B-J, Kim S-K: Fish-bone peptide increases calcium solubility and bioavailability in ovariectomised rats. Br J Nutr 2006, 95:124-128.

11. Malde M, Graff I, Siljander-Rasi H, Venäläinen E, Julshamn K, Pedersen J, Valaja J: Fish bones - a highly available calcium source for growing pigs. J Anim Physiol Anim Nutr

12. Hansen M, Sandstrom B, Jensen M, Sorensen SS: Casein phosphopeptides improve zinc and calcium absorption from rice-based but not from whole-grain infant cereal. J Pediatr Gastroenterol Nutr 1997, 24:56-62. 
13. Hansen M, Sandström B, Lönnerdal B: The effect of casein phospholipides on zinc and calcium absorption from high phytate infant diet assessed in rat pups and caco-2 cells. Pediatr Res 1996, 40:547-552.

14. Molgaard C, Sandström B, Michaelsen KF: Evaluation of a food frequency questionnaire for assessing calcium, protein and phosphorus intake in children and adolecents. Scand J Nutr 1998, 42:2-5.

15. Nordic Council of Ministers: Nordic Nutrition Recommendations 2004 Integrating nutrition and physical activity. Copenhagen, Denmark 2004.

16. Losnegård N, Bøe B, Larsen T: Undersøkelse av ekstraksjonsmidler for bestemmelse av fett. Bergen (Norway), Directorate of Fisheries 1979.

17. Julshamn K, Maage A, Wallin HC: Determination of magnesium and calcium in foods by atomic absorption spectrometry after microwave digestion: NKML collaborative study. J AOAC Int 1998, 81:1202-1208.

18. Jorhem L, Engman J: Determination of lead, cadmium, zinc, copper and iron in food by electrothermal atomic absorption spectrometry after microwave digestion: NMKL Collaborative study. J AOAC Int 2000, 83:1189-1203.

19. Fecher P, Goldman I, Nagengast A: Determination of iodine in food samples by inductive coupled plasma mass spectrometry after alkaline extraction. J Anal At Spectrom 1998, 13:977-982.

20. Julshamn K, Dahl L, Eckhoff K: Determination of iodine in seafood by inductively coupled plasma mass spectrometry. J AOAC Int 2001, 84:1976-1983

21. Norris WP, Tyler SA, Brues AM: Retention of radioactive bone-seekers. Science 1958, 128:456-462.

22. Beck AB, Bügel $S$, Stürup $S$, Jensen $M$, Mølgaard $C$, Hansen $M$, Krogsgaard OW, Sandström B: A novel dual radio- and stable-isotope method for measuring calcium absorption in humans: comparison with the whole-body radioisotope retention method. Am J Clin Nutr 2003, 77:399-405.

23. Isaksson M, Fredlund K, Sandberg A-S, Almgren A: Determination of the retention of 47Ca by whole-body counting. Appl Radiat Isot 2000, 52:1441-1450.

24. Guéguan L, Pointillart A: The bioavailability of dietary calcium. J Am Coll Nutr 2000, 19:119S-136S.

25. Recker RR: Calcium-Absorption and Achlorhydria. N Engl J Med 1985, 313:70-73.

26. Sakhaee K, Bhuket T, Adams-Huet B, Rao D: Meta-analysis of calcium bioavailability: a comparison of calcium citrate and calcium carbonate. Am J Ther 1999, 6:313-321.

27. Meier C, Woitge H, Witte K, Lemmer B, Seibel MJ: Supplementation with oral vitamin D3 and calcium during winter prevents seasonal bone loss: a randomized controlled open-label prospective trial. J Bone Miner Res 2004, 19:1221-1230.

28. Harris S, Dawson-Hughes B: Plasma vitamin D and 250HD responses of young and old men to supplementation with vitamin D3. J Am Coll Nutr 2002, 21:357-362.

29. Cashman KD, Hill T, Lucey A, Taylor N, Seamans K, Muldowney S, FitzGerald A, Flynn A, Barnes M, Horigan G, Bonham M, Duffy E, Strain J, Wallace J, Kiely M: Estimation of the dietary requirement for vitamin $D$ in healthy adults. Am J Clin Nutr 2008, 88:1535-1542.

30. Heaney RP: Phosphorus nutrition and the treatment of osteoporosis. Mayo Clin Proc 2004, 79:91-97.

31. Weast R: Handbook of chemistry and physics. Boca Raton, Florida, CRC Press 1979.

32. Schaafsma A, Beelen G: Eggshell powder, a comparable or better source of calcium than purified calcium carbonate: piglet studies. J Sci Food Agric 1999, 79:1596-1600.

33. Ishikawa M, Mori S, Watanabe H, Sakai Y: Softening of fish bone. II. Effect of acetic acid on softening rate and solubilization rate of organic matter from fish bone. J Food Process Preserv 1989, 13:123-132.

34. Shimosaka C: Relationship between the chemical composition and chrystalline structure of fish bone cured in an acetic acid solution. J Clin Biochem Nutrn 2002, 31:9-17.
35. Shimosaka C, Shimomura M, Terai M: Changes in the physical properties and composition of fish bone cured in an acetic acid solution. $J$ Home Econ Jpn 1998, 49:873-879.

36. Shimosaka C, Shimomura M, Terai M: Changes in the physical properties and composition of fish bone during cooking by heating under normal pressure. J Home Econ Jpn 1996, 47:1213-1218.

37. Shimosaka C: Relationship between chemical composition and crystalline structure in fish bone during cooking. J Clin Biochem Nutr 1999, 26:173-182.

doi:10.1186/1743-7075-7-61

Cite this article as: Malde et al: Calcium from salmon and cod bone is well absorbed in young healthy men: a double-blinded randomised crossover design. Nutrition \& Metabolism 2010 7:61.

\section{Submit your next manuscript to BioMed Central and take full advantage of:}

- Convenient online submission

- Thorough peer review

- No space constraints or color figure charges

- Immediate publication on acceptance

- Inclusion in PubMed, CAS, Scopus and Google Scholar

- Research which is freely available for redistribution

Submit your manuscript at www.biomedcentral.com/submit 